\title{
Measuring Language Learners' Success Oriented Motivation
}

\author{
Murat Polat \\ Dr., Anadolu University, Turkey, mpolat@anadolu.edu.tr
}

\begin{abstract}
Turkish language learners' motivation is affected by a number of internal and external factors such as the reasons why they learn a language, when and how long they learn it and what happens if they fail to learn it well enough to pass the required tests in a specific time. In Turkey, most university students (if they are not proficient) have to learn a foreign language for at least one year in language schools of the universities they are admitted to. Some of these students receive this language education voluntarily, whereas the others have a compulsory language education; therefore, motivation of the learners towards language learning is highly critical. In this study, success-oriented motivation of students at a language school was investigated in terms of their gender, language levels, faculties, achievement scores, university choice rankings and their willingness to learn a foreign language. 678 students from 10 different faculties of two state universities in Eskişehir participated in this study. The students' motivation of success was measured with "Success Oriented Motivation Scale" and the results revealed that there is a positive and significant relationship between success-oriented motivation and language proficiency scores.
\end{abstract}

Keywords: language learners' motivation, intrinsic motivation, extrinsic motivation, academic achievement, EFL

\section{INTRODUCTION}

Motivation in learning a foreign language has a significant role which makes the language teachinglearning process fast, easy and continuous. To illustrate, motivation is the igniter of the senses like curiosity, interest, scheduling and finally getting on action for an individual in its own learning. It is the motivation itself that makes enthusiastic language learners by planting in their minds the seeds of curiosity, self-confidence and self-direction. Needless to say, the curiosity to learn a simple or a complex skill is mostly the initial stage to start learning. Tucker et al. (2002) stated that motivation is the key factor in students' dedication in learning, the higher it is, the easier the learning and teaching are. This is a clear example that learning is a cognitive process and motivation of the learner helps the individual sustain a deep and long-lasting learning. Ulusoy (2007) claimed that an unmotivated student would never be ready to learn something; therefore, student motivation is critical in any educational process. A number of other researchers have also supported this idea and added that although it could be hard to measure and identify students' motivation at schools, it is evident that motivated students learn faster and better than the others, thus school administrations should investigate what makes their learners motivated or demotivated regularly to revise their teaching and learning activities (Fidan, 1985; Karagüven, 2012; Senemoğlu, 2007).

According to Uzbaş (2009), teachers and counselors believe that the most important problem among primary and secondary school children was the lack of motivation and the difficulty of increasing motivation in the classes. Most teachers, therefore, have a hard time teaching effectively and keeping the students on the same track because of the lack of necessary motivation. That is why Öncül (2000) and Morgan (1984) defined "motivation" as the art of keeping the students on the same line and the profession of directing them to the desired way. Therefore, it is evident that the utmost quality of being

Citation: Polat, M. (2020). Measuring Language Learners' Success Oriented Motivation. Anatolian Journal of Education, 5(2), 151-162. https://doi.org/10.29333/aje.2020.5213a 
a good language learner is to have the necessary motivation. To be able to learn a language and be a fluent speaker and writer of it, one should have the necessary motivation (Eggen \& Kauchak, 2001). This is also true for the other members of a class including the classmates and the teacher. To keep their motivations high, schools have to provide the necessary learning and teaching environments so that their students feel that they are supported, understood and cared (Bos \& Vaughn, 2002).

\section{The Relationship between Success-Oriented Motivation \& Language Learning}

Success-oriented motivation is not a new phenomenon. In many motivation-focused studies, the relationship between motivation and success and how they are inter-related were examined (Braten \& Olaussen, 2005; Singh, 2011; Thompson \& Mintzes, 2002, Woolfolk, 1999). However, the term "success-oriented" was first defined by McClelland (1961) as a human instinct which outlines three basic needs: a desire for success (1), a desire for participation (2) and a desire for leadership (3). The author stated that these desires are acquired and shaped by the individual in time with the help of motivation on the way of success. For that reason, many education researchers agreed that successoriented motivation is a powerful predictor of academic skills, academic success and goal achievement (Ahmad \& Rana, 2012; Liao et al.,2012; Weaver,1998). It is known by most teachers that when learners are persuaded, they do their best to participate, to lead and to achieve the predetermined goals and all these happen with minimum effort and maximum joy proposed that their success-oriented motivation level is kept at a satisfactory level (Keller, 2010; Chan et al. 2012).

High motivation cannot be provided solely by the teacher, what is more, the learner at the very beginning should be eager to learn. Therefore, motivation has dimensions considering the source and its reasons. There are two main sources of motivation which stem from intrinsic and extrinsic factors. Barret et al. (2005) defined social effect, social pressure, punishment and prize as the extrinsic factors for motivation. On the other hand, Ryan \& Deci (2000) categorized intrinsic motivation as the individual attitudes, values, necessities and personal ethics. The effect of all those extrinsic and intrinsic values on an individual's motivation may vary according to the case, time and the intended outcome. If somebody really wants to learn, let's say a foreign language, he/she derives his/herself on its own, sets its goals and initiates an action (Ünal \& Bursal1,2013). Thus, high intrinsic motivation of a learner could make any educational activity easier, faster and cheaper to do. As for the extrinsic motivation; parents, teachers and school administrations take the leading roles. Parents and schools should support and encourage the learners to proceed on the desired learning paths (Duit \& Treagust, 2003).

However, either it is intrinsic or extrinsic, the main motivation in any kind of learning is to have the success and to achieve the educational goals. Considering this fact, the model which was proposed by McClelland et al. (1976) is really important in understanding the direct link between academic success and success-oriented motivation. In their model, the key point for the learner is have self-confidence and prepare to do whatever it takes to have the success. Also, Martinez (2011) reported that understanding the outlying factors of success-oriented motivation is critical in order to keep control on students and boost their enthusiasm in learning a foreign language. From a broader perspective success-oriented motivation represents a general, achievement-based trend that triggers accomplishment and leads the individual to succeed and feel better. Therefore, success-oriented motivation requires individuals to be prone to achieve different goals and not to be afraid of failure since this is a part of the path leading to success (Schunk, 2009).

Needless to say, the pace of language learning is influenced by various motivational factors, including the value of work done, academic and individual goals and the most importantly the reason why that language is learnt as Lightbown \& Spada (2006) asserted, the variables that affect motivation in language learning can affect the individuals' learning positively or negatively. Talking about language learning, it is mostly agreed that it is a long and difficult process which requires a great patience and effort. If motivation for success is identified as a cognitive and affective effort to be competent in 
challenging activities ((Wigfield \& Eccles, 2000; Dweck,1999), success-oriented motivation levels of language learners, thus, may be significantly important in their language learning achievements because in many cases successful students tend to see their talent and effort as the cause of their success, and lack of effort as the cause of their failure (Weawer, 1998). Therefore, their level of motivation also determines their level of academic achievement. That's why, personal goals such as being successful, taking the leading role in a language class and being praised by the family and the instructors increase not only the motivation but also the success in language learning.

All in all, defining language learners' success-oriented motivation levels, understanding the variables which directly affect students' motivation levels and examining the possible links between students' academic achievements and motivation levels would help language teachers and administrations of language schools about the possible causes of success or failure in different cases. This research aims to measure the success-oriented motivation levels of language learners studying at a university. For this purpose, answers were sought for the following questions:

1. What are the success-oriented motivation levels of language learners?

2. Is there a relationship between language learners' success-oriented motivation levels and their language proficiency scores?

3. Do the success-oriented motivation levels of language learners differ according to gender, language level, faculty, preferences in language learning and university choice variables?

\section{METHOD}

This study was carried out between 2018 and 2019 in Eskişehir. The relational screening model was applied and convenience sampling technique was used for data collection as Büyüköztürk et al. (2011) suggested that screening research could be a good option in studies aiming to collect data to determine certain characteristics of a specific group.

\section{Participants}

After taking the official permission from the administration of the language school, a total of 2380 students from 4 different language proficiency levels (from D (the lowest) to A level (the highest)) were invited to contribute to the study; however, 684 students voluntarily participated in the research. 6 of these participants were excluded since they didn't answer the questions of the scale partly or completely, so a total of 678 students took part in the research. There was a homogeneous distribution among participants in terms of gender (332 females, 346 males), faculty (about 60 students from 10 different faculties) and language proficiency levels (about 160 students from each of the four different levels). Age range of the participants was between 18-24 and all the students were language learners coming from two state universities of Eskişehir.

\section{Data Collection Tool}

The data collection tool of this study was developed by Semerci (2010) with the contribution of 827 university students from 5 state universities in Turkey. This scale was developed as a Likert scale which has response codes ranging from 1-5 (1: totally disagree, 5: totally agree). Semerci (2010) reported that there were 4 factors (External Effects, Internal Effects, Target Extension, Selfconsciousness) in this 35 -item scale. The total variance explained by the four-factor structure in his study was 38\% and the reliability of Success oriented Motivation Scale (SOMS) was calculated as 89.6. Findings of this present study revealed that Cronbach Alpha Coefficient value was 82.1, which was close to the reliability value gained in the original scale development study.

\section{Data Analysis}

Before analyzing the data gathered from language learners, a normality test was conducted to see if the distribution of the responses was normal. Both Kolmogorov-Smirnov and Shapiro-Wilk Tests revealed that there was a normal distribution in the data set $(\mathrm{p}>.05)$. Thus, parametric tests such as Pearsons 
Correlation Test, t-test, ANOVA (one way) and Tukey tests (to investigate the source of variance for the significant results gathered from variance analysis) were utilized using IBM SPSS 22 .

\section{FINDINGS}

Before presenting the findings driven from the language learners' responses about their Success Oriented Motivation (SOM) levels, it could be better to have a look at the demographic figures of the 678 participants. Table 1 reveals the necessary information about the study group assembled according to a number of variables such as gender, faculty, language proficiency, reason of language learning and university choice ranking.

Table 1

Demographic Info of the Study Group

\begin{tabular}{llll}
\hline \multirow{3}{*}{ Gender } & Female & $f$ & $\%$ \\
\cline { 2 - 3 } Faculty & Male & 332 & 48.97 \\
& Total & 346 & 51.03 \\
& 1. Engineering & 678 & 100 \\
& 2. Pharmacy & 85 & 12.5 \\
3. Fine Arts & 79 & 11.7 \\
& 4. Literature & 60 & 8.8 \\
& 5. Business Administration & 57 & 8.4 \\
& 6. Sports & 84 & 8.1 \\
& 7. Communication & 71 & 12.4 \\
& 8. Education & 62 & 10.6 \\
& 9. Aviation & 64 & 9.1 \\
Language Proficiency & 10.Science & 61 & 9.4 \\
& Total & 678 & 9 \\
& A & 124 & 100 \\
& B & 173 & 25.3 \\
Language Education & D & 182 & 26.8 \\
& Total & 199 & 29.4 \\
University Choice & Compulsory & 678 & 100 \\
& Optional & 479 & 70.6 \\
& Total & 199 & 29.4 \\
& First 3 & 678 & 100 \\
& 4th or other choices & 380 & 56.5 \\
& Total & 298 & 43.5 \\
\hline
\end{tabular}

The demographic information of the participants presents a homogeneous distribution in each independent variable except the reason why students learn a foreign language. The students who take compulsory language education was about $70 \%$ of the whole population. The reason of this difference is that, in Turkish state universities, the decision about foreign language proficiency and the demand according to this proficiency level is taken by each faculty's senate. That is why, some students may not take the language education (students' decision, it is optional) whereas others (depending on their faculties' decision) have to take a one-year compulsory language education if they cannot pass the foreign language proficiency exam which is prepared by each university. Also, the number of D level students (it should be noted that unlike CEFR criteria D level is the lowest language proficiency level at the language school from which the data of the study were collected) was the highest since in this language school the most populated language level has always been the lowest grade since sustaining a suscessful language learning has often been problematic until the university classes in Turkey. 
Table 2

Success-Oriented Motivation Scale Statistics

\begin{tabular}{llrccc}
\hline \multirow{5}{*}{ SOMS } & Factors & \multicolumn{1}{c}{ Min. } & Max. & X & SD \\
\cline { 2 - 5 } & External Effects & 14.00 & 60.00 & 49.12 & .37 \\
& Internal Effects & 10.00 & 45.00 & 29.65 & .69 \\
& Target Extension & 8.00 & 35.00 & 26.34 & .28 \\
& Self-consciousness & 8.00 & 35.00 & 25.74 & .26 \\
\hline
\end{tabular}

In Table 2 participants' mean scores taken from the motivation scale were presented. For each factor, the maximum and minimum mean scores were given separately and the scores presented a relatively high motivation level especially in "external effects" and "target extension" sub-dimensions. Considering the fact that the maximum score in external factors was calculated as 60 , the average score (49.12) in this sub-dimension was considerably high. The highest mean scores among all the factors were taken from "External effects". When the items of this factor were examined item 36 (" $A$ warm atmosphere in the class increases my success.") and item 34 ("I am positively affected if the teacher is eager to teach.") had the highest mean scores among the other items. These results can be interpreted as the importance of a positive classroom environment and an encouraging teacher manner in the language teaching \& learning process. Considering the fact that language learning is a long and difficult task, those two factors are important and should never be ignored in classes. When the lowest mean score in all sub-categories was observed, it was found that it was in "Internal effects". This could be a critical finding since students' intrinsic motivation is highly valuable in language learning. When the items of this factor were checked, the mean scores especially, for item 13 ("I prepare before going to the language classes.") and 20 ("I like studying") were calculated as the lowest ones. As it was mentioned before, university students take this language education immediately after they start university and this brings a lot of washback effects including weariness and an uncontrolled relaxation after passing a tough test. It might be difficult to regain intrinsic motivation for another struggle to learn a foreign language and pass another tough test so students' low mean scores in terms of intrinsic motivation could be foreseen due to the university exam.

Table 3

Correlation between SOMS and Language Proficiency Scores of the Participants

\begin{tabular}{|c|c|c|c|c|c|c|c|}
\hline \multirow{3}{*}{ Ext. Eff. } & & Ext. Eff. & Inter. Eff. & Targ. Ext. & Self-c. & Total & Lang.Sco. \\
\hline & $\mathrm{r}$ & 1 & $.62 * *$ & $.64 * *$ & $.58 * *$ & $.88^{* * *}$ & $.24 * *$ \\
\hline & $\mathrm{P}$ & .00 & .00 & .0 & .00 & .00 & .00 \\
\hline \multirow{4}{*}{ Int. Eff. } & $\mathrm{N}$ & 678 & 678 & 678 & 678 & 678 & 678 \\
\hline & $\mathrm{r}$ & $.56^{* *}$ & 1 & $.52 * *$ & $.56^{* *}$ & $.79 * *$ & $.22 * *$ \\
\hline & $\mathrm{P}$ & .00 & .00 & .00 & .00 & .00 & .00 \\
\hline & $\mathrm{N}$ & 678 & 678 & 678 & 678 & 678 & 678 \\
\hline \multirow[t]{3}{*}{ Target Ext. } & $\mathrm{r}$ & $.48 * *$ & $.51 * *$ & 1 & $.52 * *$ & $.78 * *$ & $.21 * *$ \\
\hline & $\mathrm{P}$ & .00 & .00 & .00 & .00 & .00 & .00 \\
\hline & $\mathrm{N}$ & 678 & 678 & 678 & 678 & 678 & 678 \\
\hline \multirow[t]{3}{*}{ Self-cons. } & $\mathrm{r}$ & $.53 * *$ & $.55 * *$ & $.59 * *$ & 1 & $.76^{* * *}$ & $.20 * *$ \\
\hline & $\mathrm{P}$ & .00 & .00 & .00 & .00 & .00 & .00 \\
\hline & $\mathrm{N}$ & 678 & 678 & 678 & 678 & 678 & 678 \\
\hline \multirow[t]{3}{*}{ Total } & $\mathrm{r}$ & $.88^{* *}$ & $.79 * *$ & $78 * *$ & $.76^{* *}$ & 1 & $.22 * *$ \\
\hline & $\mathrm{P}$ & .00 & .00 & .00 & .00 & .00 & .00 \\
\hline & $\mathrm{N}$ & 678 & 678 & 678 & 678 & 678 & 678 \\
\hline \multirow[t]{3}{*}{ Lang. Sco. } & $\mathrm{r}$ & $.24 * *$ & $.22 * *$ & $.21 * *$ & $.20 * *$ & $.22 * *$ & 1 \\
\hline & $\mathrm{P}$ & .00 & .00 & .00 & .00 & .00 & .00 \\
\hline & $\mathrm{N}$ & 678 & 678 & 678 & 678 & 678 & 678 \\
\hline
\end{tabular}

significant at $* * .01$ 
The results presented in Table 3 reveal that all the sub-dimensions of the Success Oriented Motivation Scale have positive and significant relationships $(\mathrm{r}=.62, \mathrm{p}<.01)$ with each other. It is also clear that there are positive correlations $(r=.24$ and $\mathrm{p}<.01)$ between all sub-dimensions of the scale and students' average language proficiency scores. Thus, it can be interpreted that as the scores obtained from any sub-dimension of the scale increase, the average language proficiency scores of the learners increase. As a result, it has been determined that there is a positive relationship between success-oriented motivation and language proficiency scores.

Table 4

Gender Difference Independent Samples t-test

\begin{tabular}{llcccc}
\hline \multirow{2}{*}{ External Effects } & Gender & $\mathrm{N}$ & Mean & SD & $\mathrm{p}$ \\
\cline { 2 - 5 } Internal Effects & Female & 332 & 48.26 & 7.63 & $.00^{* *}$ \\
& Male & 346 & 44.11 & 7.58 & \\
\multirow{2}{*}{ Target Extension } & Female & 332 & 30.58 & 6.15 & $.00^{* *}$ \\
\multirow{3}{*}{ Self-consciousness } & Male & 346 & 27.39 & 6.24 & \\
\multirow{2}{*}{ SOMS Total } & Female & 332 & 23.69 & 5.13 & .29 \\
& Male & 346 & 23.30 & 5.57 & \\
\multirow{2}{*}{ Language Scores } & Female & 332 & 24.62 & 5.07 & .56 \\
& Male & 346 & 24.69 & 5.16 & \\
& Female & 332 & 127.15 & 20.42 & $.00^{* *}$ \\
& Male & 346 & 119.49 & 20.24 & \\
& Female & 332 & 73.54 & 9.18 & .54 \\
\hline
\end{tabular}

The analysis in Table 4 shows the t-test scores and standard deviations of the students who participated in the study regarding their gender differences. The results of the t-test revealed that female students' motivation levels were significantly different according to "external effects" and "internal effects" sub-dimensions of the motivation scale $(\mathrm{p}<.01)$. When the mean sores of each factor were checked, it was found that female participants had significantly higher scores in the motivation measurement regarding the external and internal effects. This difference was also significant in the total scores of the participants, females' motivation scores were significantly higher than the males' scores in SOMS total scores $(\mathrm{p}<.01)$. However, it was interesting that this significant difference was not visible when the language proficiency scores were compared.

Table 5

Language Education Choice Independent Samples t-test

\begin{tabular}{lllllc}
\hline \multirow{3}{*}{ External Effects } & Lang. Education & $\mathrm{N}$ & Mean & $\mathrm{SD}$ & $\mathrm{p}$ \\
& Compulsory & 479 & 47.92 & 7.93 & $.00^{* *}$ \\
& Optional & 199 & 43.71 & 8.07 & \\
Internal Effects & Compulsory & 479 & 29.58 & 6.53 & $.00^{* *}$ \\
& Optional & 199 & 26.42 & 6.37 & \\
Target Extension & Compulsory & 479 & 24.20 & 6.28 & .81 \\
& Optional & 199 & 24.26 & 6.24 & \\
Self-consciousness & Compulsory & 479 & 24.60 & 5.73 & $.00^{* *}$ \\
& Optional & 199 & 24.14 & 5.61 & \\
SOMS Total & Compulsory & 479 & 126.30 & 18.12 & $.00^{* *}$ \\
& Optional & 199 & 118.53 & 17.96 & \\
Language Scores & Compulsory & 479 & 74.62 & 9.18 & $.00 * *$ \\
& Optional & 199 & 67.69 & 8.93 & \\
\hline
\end{tabular}

significant at $* * .01$ 
Language education is not compulsory for all university students in Turkey; in some faculties like Aviation or Sports' sciences students are given the option to make their decisions on their own, that is they choose if they would like to start their education in their departments directly or have a one-year language education. In Table 5, motivation level differences of those two types were presented. The results of the t-test revealed that motivation levels of students who take compulsory language education were significantly different according to "external effects", "internal effects" and "selfconsciousness" sub-dimensions of the motivation scale $(\mathrm{p}<.01)$. When the mean sores of each factor were checked, it could be understood that students who had compulsory language learning had significantly higher scores in the motivation measurement regarding the external \& internal effects and self-consciousness. This difference was also visible in the total scores of the participants, students who took compulsory education had significantly higher scores than the ones who had optional language education in SOMS total scores $(\mathrm{p}<.01)$. Language proficiency score means also proved this fact since students who had compulsory language learning had significantly higher scores ( $\mathrm{p}<.01)$.

Table 6

University Preference Independent Samples t-test

\begin{tabular}{|c|c|c|c|c|c|}
\hline & Uni.Pref. & $\mathrm{N}$ & $X$ & SD & $\mathrm{p}$ \\
\hline \multirow{2}{*}{ External Effects } & First 3 & 380 & 47.28 & 8.13 & \multirow{2}{*}{.24} \\
\hline & The other & 298 & 46.96 & 7.26 & \\
\hline \multirow{2}{*}{ Internal Effects } & First 3 & 380 & 30.13 & 5.95 & \multirow{2}{*}{.61} \\
\hline & The other & 298 & 30.25 & 5.63 & \\
\hline \multirow{2}{*}{ Target Extension } & First 3 & 380 & 24. 44 & 4. 85 & \multirow{2}{*}{.49} \\
\hline & The other & 298 & 23.94 & 4. 39 & \\
\hline \multirow{2}{*}{ Self-consciousness } & First 3 & 380 & 24.86 & 3.92 & \multirow{2}{*}{.41} \\
\hline & The other & 298 & 24.34 & 3.21 & \\
\hline \multirow{2}{*}{ SOMS Total } & First 3 & 380 & 127.58 & 21.13 & \multirow{2}{*}{.36} \\
\hline & The other & 298 & 126.92 & 18.91 & \\
\hline \multirow{2}{*}{ Univ. Preference } & First 3 & 380 & 74.47 & 8.88 & \multirow{2}{*}{.44} \\
\hline & The other & 298 & 73.60 & 9.31 & \\
\hline
\end{tabular}

significant at *.05

Students' university preference was considered as another important independent variable in students' motivation. In Turkey, after the university entrance exam, students are asked to make university and department preferences according to the points they took from the test. Students list their university preferences in the order they prioritize and the first 3 preferences are generally the universities that students would like to be admitted the most. In Table 6, motivation level comparisons of participants regarding their university preferences were given. It could be seen that under no factors did the motivation mean scores differ significantly ( $>.05)$. The same finding was also true when their language proficiency scores were compared, there was no significant difference $(\mathrm{p}>.05)$. 
Table 7

ANOVA Results According to Faculty Differences

\begin{tabular}{|c|c|c|c|c|c|c|c|}
\hline & Faculties & SD & DF & MS & $\mathrm{F}$ & $\mathrm{p}$ & $\begin{array}{l}\text { Tukey } \\
\text { Results }\end{array}$ \\
\hline \multirow{3}{*}{ Ext. Eff. } & Between Gr. & 367.81 & 9 & 40.86 & 1.05 & \multirow[t]{3}{*}{.67} & \\
\hline & \multirow{3}{*}{$\begin{array}{l}\text { Within Gr. } \\
\text { Total } \\
\text { Between Gr. }\end{array}$} & 25924.54 & 668 & 38.80 & & & \\
\hline & & 29607.35 & 677 & & \multirow{4}{*}{3.79} & & \\
\hline \multirow{3}{*}{ Inter. Ef. } & & 898.45 & 9 & 99.83 & & \multirow[t]{3}{*}{$.00 * *$} & \multirow{3}{*}{$\begin{array}{l}1>3,1>6, \\
6>2,6>4\end{array}$} \\
\hline & \multirow{3}{*}{$\begin{array}{l}\text { Within Gr. } \\
\text { Total } \\
\text { Between Gr. }\end{array}$} & 17635.60 & 668 & 26.40 & & & \\
\hline & & 18534.05 & 677 & & & & \\
\hline \multirow{3}{*}{ Tar. Ext. } & & 422.54 & 9 & 46.95 & 2.59 & \multirow{3}{*}{$.00 * *$} & \multirow{3}{*}{$1>4,1>7$} \\
\hline & \multirow{3}{*}{$\begin{array}{l}\text { Within Gr. } \\
\text { Total } \\
\text { Between Gr. }\end{array}$} & 12114.00 & 668 & 18.13 & & & \\
\hline & & 12536.54 & 677 & & & & \\
\hline \multirow{3}{*}{ Self-cons. } & & 360.36 & 9 & 40.04 & 1.10 & \multirow{3}{*}{.39} & \\
\hline & Within Gr. & 24227.48 & 668 & 36.26 & & & \\
\hline & Total & 24587.84 & 677 & & & & \\
\hline \multirow{3}{*}{$\begin{array}{l}\text { SOMS } \\
\text { Total }\end{array}$} & Between Gr. & 12796.63 & 9 & 1421.8 & 5.44 & \multirow[t]{3}{*}{$.00 * *$} & $\begin{array}{l}1>4,1>5, \\
1>9,6<2\end{array}$ \\
\hline & Within Gr. & 174625.35 & 668 & 261.42 & & & $6<2,6<3$, \\
\hline & Total & 187421.98 & 677 & & & & $6<4,8<5$ \\
\hline \multirow{3}{*}{ Lan. Sco. } & Between Gr. & 2168.72 & 9 & 240.97 & 6.10 & \multirow{3}{*}{$.00 * *$} & $\begin{array}{l}1>3,1>5, \\
1>4,1>6\end{array}$ \\
\hline & Within Gr. & 26368.45 & 668 & 39.47 & & & $\begin{array}{l}1>7,1>8, \\
6<2,6<4,\end{array}$ \\
\hline & Total & 28537.17 & 677 & & & & $\begin{array}{l}6<5,6<7, \\
6<9\end{array}$ \\
\hline
\end{tabular}

significant at $* * .01$

ANOVA test results given in Table 7 show the differences in success-oriented motivation total scores, sub-dimension scores and academic averages of the language learners according to their faculties. The results of the variance analysis showed that success-oriented motivation total scores $(\mathrm{f}=5.44, \mathrm{p}<.01)$, language proficiency scores $(\mathrm{f}=6.1, \mathrm{p}<.01)$ and the factors including internal effects $(\mathrm{f}=3.79, \mathrm{p}<.01)$ and target extension $(\mathrm{f}=2.59, \mathrm{p}<.01)$ differed significantly according to the faculties of the participants. This result revealed that students' faculties had significant effects on their motivation levels in language learning. As Büyüköztürk et al. (2011) advised, when the variety of means in one-way analysis of variance is deemed important, a Tukey test is carried out in order to determine from which means the difference stems from in the study group. Results of the Tukey test showed that Engineering and Sports Faculties were main reasons of the significant differences in the variance analysis in success-oriented motivation total scores, language proficiency scores and the factors including internal effects and target extension. Engineering Faculty students had significantly higher motivation levels including success-oriented motivation total scores, internal effects and target extension sub-dimensions and language proficiency scores than most of the other faculty students; whereas Sports Faculty students had significantly lower motivation levels and language scores than most of the other faculty students $(\mathrm{p}<.01)$. 
Table 8

ANOVA Results According to Language Level Differences

\begin{tabular}{|c|c|c|c|c|c|c|c|}
\hline \multirow{4}{*}{$\begin{array}{l}\text { Ext. } \\
\text { Effect }\end{array}$} & \multirow{2}{*}{$\begin{array}{l}\text { Lang. Levels } \\
\text { Between Groups }\end{array}$} & SD & DF & MS & $\mathrm{F}$ & $\mathrm{p}$ & Tukey Test \\
\hline & & 831.72 & 3 & 277.2 & \multirow[t]{3}{*}{6.87} & \multirow[t]{3}{*}{$.00 * *$} & \multirow{3}{*}{$\begin{array}{l}1>2,1>3, \\
1>4,2>4, \\
3>4\end{array}$} \\
\hline & Within Groups & 27196.45 & 674 & 40.35 & & & \\
\hline & Total & 27228.17 & 677 & & & & \\
\hline \multirow{3}{*}{$\begin{array}{l}\text { Inter. } \\
\text { Effect }\end{array}$} & Between Groups & 263.36 & 3 & 87.79 & \multirow[t]{3}{*}{3.14} & \multirow{3}{*}{$.00 * *$} & \multirow{3}{*}{$1>3,1>4$} \\
\hline & Within Groups & 18802.60 & 674 & 27.89 & & & \\
\hline & Total & 19065.96 & 677 & & & & \\
\hline \multirow{3}{*}{$\begin{array}{l}\text { Target } \\
\text { Ext. }\end{array}$} & Between Groups & 142.54 & 3 & 47.51 & \multirow[t]{3}{*}{1.60} & & \\
\hline & Within Groups & 19928.36 & 674 & 29.57 & & .079 & \\
\hline & Total & 20070.90 & 677 & & & & \\
\hline \multirow{3}{*}{$\begin{array}{l}\text { Self- } \\
\text { consci. }\end{array}$} & Between Groups & 133.42 & 3 & 45.47 & \multirow[t]{3}{*}{1.62} & & \\
\hline & Within Groups & 18968.18 & 674 & 28.14 & & .080 & \\
\hline & Total & 19101.60 & 677 & & & & \\
\hline \multirow{3}{*}{$\begin{array}{l}\text { SOMS } \\
\text { Total }\end{array}$} & Between Groups & 2768.09 & 3 & $\begin{array}{l}922.3 \\
6\end{array}$ & \multirow[t]{2}{*}{3.36} & $00 * *$ & \multirow[b]{2}{*}{$1>3,1>4$} \\
\hline & Within Groups & 185135.49 & 674 & $\begin{array}{l}274.6 \\
9\end{array}$ & & .00 & \\
\hline & Total & 187903.58 & 677 & & \multirow{4}{*}{3.99} & \multirow{4}{*}{$.00 * *$} & \multirow{4}{*}{$\begin{array}{l}1>2,1>3 \\
1>4\end{array}$} \\
\hline \multirow{3}{*}{$\begin{array}{l}\text { Lang.S } \\
\text { cores }\end{array}$} & Between Groups & 1925.18 & 3 & $\begin{array}{l}641.7 \\
3\end{array}$ & & & \\
\hline & Within Groups & 108596.52 & 674 & $\begin{array}{l}161.1 \\
2\end{array}$ & & & \\
\hline & Total & 110521.70 & 677 & & & & \\
\hline
\end{tabular}

ANOVA test results given in Table 8 reveal the differences in success-oriented motivation total scores, sub-dimension scores and academic averages of the language learners according to their language levels. It should be reminded again that A level (in Tukey Test column presented as 1) is the highest, D level (in Tukey Test column presented as 4) is the lowest level in the language school from which the data were collected. The results of the variance analysis showed that success-oriented motivation total scores $(\mathrm{f}=3.36, \mathrm{p}<.01)$, language proficiency scores $(\mathrm{f}=3.99, \mathrm{p}<.01)$ and the factors including external effects $(\mathrm{f}=6.87, \mathrm{p}<.01)$ and internal effects $(\mathrm{f}=3.14, \mathrm{p}<.01)$ differed significantly according to the language levels of the participants. This result proved that students' language proficiency levels had significant effects on their motivation levels. It could be assumed that the higher the language level, the more motivated the language learner. Results of the Tukey test showed that A level language learners were the main reason of the significant differences in the variance analysis in success-oriented motivation total scores, language proficiency scores and the factors including internal effects and target extension. A level students had significantly higher motivation levels including success-oriented motivation total scores, external and internal effects and and language proficiency scores than all the other levels; whereas D level students had significantly lower motivation levels and language scores than the other levels $(\mathrm{p}<.01)$. This finding once again underlined the importance of academic success in motivation.

\section{DISCUSSION \& CONCLUSION}

The present study which was carried out between 2018 and 2019 in Eskişehir, with the contribution of 678 university students who were studying at a language school commonly used by two state universities, aimed to measure success-oriented motivation levels of the student. It was also aimed to 
find out if there was a relationship between language learners' success-oriented motivation levels and their language achievement scores and to investigate if the success-oriented motivation levels of language learners differed according to a number of independent variables such as gender, language level, faculty, language learning preference and university choice. The data collection tool of this study was developed by Semerci (2010) as a Likert scale which had response codes ranging from 1-5 (1: totally disagree, 5: totally agree) and 4 factors (External Effects, Internal Effects, Target Extension, Self-consciousness).

The findings revealed that participants had mostly high motivation levels especially in "external effects" and "target extension" sub-dimensions in the motivation scale. The highest mean scores among all the factors were taken from "External effects" and item 36 ("A warm atmosphere in the class increases my success.") and item 34 ("I am positively affected if the teacher is eager to teach.") had the highest mean scores among the other items in the same factor. The findings proved the importance of a positive classroom environment and an encouraging teacher manner in language teaching \& learning process. The lowest mean scores in all sub-categories was observed in "Internal effects" and item 13 ("I prepare before going to the language classes.") and 20 ("I like studying") were calculated as the lowest ones. As it was mentioned before, university students take this language education immediately after they start university, and this brings many washback effects including weariness and an uncontrolled relaxation after passing a tough test which might negatively influence language learning and teaching. It has also been determined that there is a positive and significant relationship between success-oriented motivation and language proficiency scores. Thus, it is possible to conclude that as the mean scores obtained from any sub-dimension of the success-oriented motivation scale increase, the average language proficiency scores of the learner's increases.

Another research question of the study was to investigate if the success-oriented motivation levels of language learners differed according to a number of independent variables such as gender, language level, faculty, language learning preference and university choice. The results of the study showed that female participants had significantly higher motivation levels than the male participants, which was also reported by a number of researchers (Alemdağ et al. 2014; Eymur \& Geban, 2011). Considering the participants' university preferences, their motivation levels and language scores did not differ significantly, it could be interpreted that university preference rankings had no significant impact on language learners' motivation levels. However, in terms of language level differences, motivation levels of the participants differed positively as their language levels increase. The lowest language level students (D level) were observed to have lower motivational levels compared to the other levels.

Participants' language learning preferences was another independent variable of this study, and the findings revealed that the students who had compulsory language education had significantly higher motivation levels than the others for whom language learning was optional. The reason of this finding could be the fear of losing a year and repeating the language class once again in case of failure; therefore, those students who were obliged to learn the target foreign language and pass the proficiency tests were observed to be more motivated. This finding was also supported by Lightbown \& Spada (2006) and Gardner \& Yung (2017) who believe that tests are indirect ways to motivate language learners' study harder and stay under educational supervision.

Finally, participants' faculty differences were examined, and it was found that students' faculties had significant effects on their motivation levels in language learning. Results of the analysis showed that Engineering and Sports Faculties were the main reasons of the significant differences in the variance analysis in success-oriented motivation total scores, language proficiency scores and the factors including internal effects and target extension. Engineering Faculty students had significantly higher motivation levels including success-oriented motivation total scores, internal effects and target extension sub-dimensions and language proficiency scores than most of the other faculty students;

Anatolian Journal of Education, October $2020 \bullet$ Vol.5, No.2 
whereas Sports Faculty students had significantly lower motivation levels and language scores than most of the other faculty students. The impact of faculty difference on motivation was also studied by Demir \& Ar1 (2013) and Najafi et al. (2018) and it was reported that the difference in the academic disciplines might have impacts on motivation types and levels, which was also proved by the finding of the present study.

A number of suggestions can be made for further research on students' success-oriented motivation levels. To begin with, this study included the language learners in a university's language school. Changing the focus group and collecting data from a high school population including different types of schools could be good idea to observe the variety in motivational level differences according to many different variables including the social status, education and income level of the parents, school choice etc. It could also be a good idea to make a qualitative study including not only the students' but also the teachers' opinions about the most effective variables on students' motivation. A list of motivating and demotivating factors for students, their frequencies and the advice teachers would give about these could be beneficial. The last but not the least, if the overall objective of most schools is to increase their students' academic achievement, the importance of motivation and the ways to increase it should be highlighted by other research, and not only the teachers and school administrations but also the students should be made aware of this critical fact.

\section{REFERENCES}

Ahmad, I., \& Rana, S. (2012). Affectivity, achievement motivation, and performance in college students. Pakistan Journal of Psychological Research, 27, 107-120.

Alemdağ, C., Öncü, E., \& Yılmaz, A. K. (2014). Preservice Physical Education Teachers’

Academic Motivation and Academic Self-Efficacy. Hacettepe Journal of Sport Sciences. 25(1), 23-35.

Barrett. D. W., Patock-Peckham, J. A., \& Nagoshi, C. T. (2005). Cognitive motivation and religious orientation. Personality and Individual Differences, 38, 461-474.

Bos, C. S., \& Vaughn, S. (2002). Strategies for Teaching Students with Learning and Behavior Problems (5th ed.). USA: Allyn and Bacon.

Braten, I., \& Olaussen, B. S. (2005). Profiling individual differences in student motivation: A longitudinal cluster analytic studying different academic contexts. Contemporary Educational Psychology, 30, 359-396.

Büyüköztürk, Ş., Kılıç Çakmak, E., Akgün, Ö. E., Karadeniz, Ş., \& Demirel, F. (2011). Scientific Research Methods, (11. Printing). Ankara: Pegem Academy.

Chan, K.W., Wong, K. Y. A., \& Lo, S. C. E. (2012). Relational analysis of intrinsic motivation, achievement goals, learning strategies and academic achievement for Hong Kong secondary students. The Asia Pacific Education Researcher, 21(2), 230-243.

Demir, M. K., \& Ar1, E. (2013). Assessing levels of academic motivation of preservice teachers in terms of various variables. Journal of Theory and Practice in Education, 9(3), 265-279.

Duit, R., \& Treagust, D. (2003). Conceptual change: A powerful framework for improving science teaching and learning. Int. Journal of Science Edu., 25(6), 671-688.

Dweck, C. S. (1999). Self-theories: Their role in motivation, personality, and development. Philadelphia: Psychology Press.

Eggen, P., \& Kauchak, D. (2001). Educational Psychology. Merrill Prentice Hall.

Eymur, G., \& Geban, Ö. (2011). An investigation of the relationship between motivation and academic achievement of pre-service chemistry teachers. Education and Science, 36 (161), 246-255.

Fidan, N. (1985). Learning and teaching at school, Ankara: Alkım Bookstore. 
Gardner, D. \& Yung, W. H. (2017) Learner motivation in self- access language learning, Innovation in Language Learning and Teaching, 11:2, 159-176, DOI: 10.1080/17501229.2015.1088545

Karagüven, H. (2012). The adaptation of academic motivation scale to Turkish. Educational Consultancy and Research Center, 12(4), 2599-2620.

Keller, J. M. (1999). Motivation in cyber-learning environments. Educational Technology International, 1(1), 7-30.

Liao, H., Ferdenzi, A. C., \& Edlin, M. (2012). Motivation, self-regulated learning efficacy, and academic achievement among international and domestic students at an urban community college: A comparison. Community College Enterprise, 18, 9-38.

Lightbown, P.M., \& Spada, N. (2006). How languages are learned. OUP. Oxford.

Martinez, P. (2001). Improving student retention and achievement: What do we know and what do we need to find out? Learning and Skills Development Agency, 1-16.

McClelland, D. C. (1961). The Achieving Society. Van Nostrand Co. Inc. Princeton.

Morgan, C. T. (1984). Introduction to psychology textbook, Ankara: Meteksan Publishing.

Najafi, H., Rolheiser, C., Harrison, L. \& Heikoop, W. (2018). Connecting Learner Motivation to Learner Progress and Completion in Massive Open Online Courses. Canadian Journal of Learning and 44(2, Canadian Network for Innovation in Education. Retrieved June 22, 2020 from https://www.learntechlib.org/p/184785/.

Öncül, R. (2000). Education and educational sciences glossary. İstanbul: National Education Printing House.

Ryan, R., \& Deci, E. (2000). Intrinsic and extrinsic motivation: Classic definitions and new directions. Contemporary Educational Psychology, 25, 54-67.

Schunk, D. H. (2009). Learning theories: From an educational perspective. Nobel Publishing.

Senemoğlu, N. (2007). Development, learning and teaching. Ankara: Gönül Publishing.

Singh, K. (2011). Study of motivation in relation to academic achievement of students. International Journal of Educational Planning \& Administration. 1(2), 161-171.

Thompson, T. L., \& Mintzes, J. J., (2002). Cognitive structure and the affective domain. International Journal of Science Education, 24(6), 645-660.

Tucker, Anita L., Amy C. Edmondson., \& Spear, S. (2002). "When Problem Solving Prevents Organizational Learning", Journal of Organizational Change Management, 15, 122-137.

Ulusoy, A. (2007). Motivation. Ankara: Anı Publushing.

Uzbaş, A. (2009). The Evaluation of School Counselors' Opinions About School Violence and Aggression. Mehmet Akif Ersoy Üniversity, Journal of Education Faculty, 18, 90-110.

Ünal, F., \& Bursal1, H. (2013). Turkish Teachers' Views About Motivation Factors. Middle E. \& African Journal of Educational Research, Issue 5, 7-16.

Weaver, G. C., (1998). Strategies in K-12 science instruction to promote conceptual change. Science Education, 82(4), 455-472.

Wigfield, A., \& Eccles, J. S., (2000). Expectancy-value theory of achievement motivation. Contemporary Educational Psychology, 25, 68-81.

Woolfolk, A. E. (1999). Educational Psychology, Bosto 